University of Wollongong

Research Online

Faculty of Social Sciences - Papers (Archive) Faculty of Arts, Social Sciences \& Humanities

$1-1-2018$

Establishing a framework for learning to teach English pronunciation in an Australian TESOL program

Michael S. Burri

University of Wollongong, mburri@uow.edu.au

Amanda Ann Baker

University of Wollongong, abaker@uow.edu.au

Honglin Chen

University of Wollongong, honglin@uow.edu.au

Follow this and additional works at: https://ro.uow.edu.au/sspapers

Part of the Education Commons, and the Social and Behavioral Sciences Commons

Research Online is the open access institutional repository for the University of Wollongong. For further information contact the UOW Library: research-pubs@uow.edu.au 


\title{
Establishing a framework for learning to teach English pronunciation in an Australian TESOL program
}

\begin{abstract}
A substantial number of studies have been conducted in various second language teacher education settings. Yet, evidence about the effectiveness of teacher preparation continues to be debated and research findings about the efficacy of preparing language teachers are still somewhat inconclusive. As a further complication, even though pronunciation has regained some of its prominence in second language teaching, only minimal understanding exists about the preparation of pronunciation instructors in teacher education. The aim of this paper is to address this gap and to advance our understanding of teacher learning by first combining the findings from four research-based articles on learning to teach English pronunciation and then by introducing a new and innovative conceptual framework that reflects effective pronunciation teacher preparation in an Australian context.
\end{abstract}

\section{Keywords}

framework, teach, english, pronunciation, australian, learning, tesol, establishing, program

\section{Disciplines}

Education | Social and Behavioral Sciences

\section{Publication Details}

Burri, M., Baker, A. \& Chen, H. (2018). Establishing a framework for learning to teach English pronunciation in an Australian TESOL program. Australian Review of Applied Linguistics, 41 (3), 307-327. 


\title{
Establishing a Framework for Learning to Teach English Pronunciation in an Australian TESOL Program
}

\author{
Michael Burri, Amanda Baker, and Honglin Chen \\ University of Wollongong
}

\begin{abstract}
A substantial number of studies have been conducted in various second language teacher education settings. Yet, evidence about the effectiveness of teacher preparation continues to be debated and research findings about the efficacy of preparing language teachers are still somewhat inconclusive. As a further complication, even though pronunciation has regained some of its prominence in second language teaching, only minimal understanding exists about the preparation of pronunciation instructors in teacher education. The aim of this paper is to address this gap and to advance our under- standing of teacher learning by first combining the findings from four research-based articles on learning to teach English pronunciation and then by introducing a new and innovative conceptual framework that reflects effective pronunciation teacher preparation in an Australian context.
\end{abstract}

Keywords: second language teacher education, teacher cognition, teacher beliefs, oral communication, pronunciation

\section{Introduction}

Since the mid-1980s, pronunciation instruction and learning has gradually shed its cloak as the "Cinderella of language teaching" (Kelly, 1969, p. 87) and regained its legitimate place in second language (L2) classrooms (Levis, 2015; Thomson \& Derwing, 2015). This renewed interest in pronunciation pedagogy is evident through numerous outlets, including an increasing growth in empirical, class- room-based research (see Lee, Jang, \& Plonsky, 2015; Saito, 2012, for reviews), the establishment of the Journal of L2 Pronunciation, regular pronunciation-oriented conferences and symposiums held worldwide (e.g., Pronunciation in L2 Learning and Teaching conference in North America; the Pronunciation Symposium in Australia) along with the recent publication of several pronunciation-related resources (e.g., Derwing \& Munro, 2015; Kang, Thomson, \& Murphy, 2018; Reed \& Levis, 2015).

An important insight gained from this development is that mutual intelligibility between speakers rather than native-like pronunciation should be seen as the central pedagogical goal (Litzenberg, 2014; Thomson, 2014). Nonetheless, research continues to demonstrate that L2 instructors not only find pronunciation to be one of the most challenging aspects to teach, but that they often lack confidence and skills to incorporate and address pronunciation in their classrooms (Baker, 2014; Couper, 2017). One of the main reasons for these challenges is that learning to teach pronunciation still receives limited attention in second language teacher education (SLTE) (Foote, Holtby, \& Derwing, 2011; Murphy, 2014).

This background provided initial impetus for the research reported in this paper. Additional motivation stemmed from the desire to contribute to the growing body of SLTE literature and research (Wright, 2010; Wright \& Beaumont, 2015). In the late 1990s, Freeman and Johnson (1998) called for a reconceptualization of L2 teacher education, and nearly a decade later, 
Johnson (2006) advocated the importance of a sociocultural approach to L2 teacher learning. More recently, Farrell (2015b) suggested that SLTE had lost some of its effectiveness because pro- grams do not prepare "teacher learners adequately about how to deal with the realities of teaching in the classroom" (p. 2). Thus this paper aims to extend the current conversation about teacher learning and introduce - through consolidating four research studies - an empirically-based model for effective pronunciation teacher preparation situated within one specific Australian context.

\section{Second Language Teacher Education and Pronunciation Teacher Preparation}

With the global spread of the English language, the demand for trained English teachers continues to increase (Wright, 2010). Growing interest in the preparation of L2 teachers has emerged as a means to address this demand, and SLTE - a term first used by Richards (1990) to foreground L2 teacher learning - has become an important aspect of Teaching English to Speakers of Other Languages (TESOL) (Burns \& Richards, 2009). Despite this, research has produced somewhat inconclusive evidence about the effectiveness of preparing L2 instructors to teach language in their classrooms. Some studies suggest that SLTE has only a limited impact on teachers' professional growth (e.g., Macalister, 2016; Ogilvie \& Dunn, 2010; Peacock, 2001; Tang, Lee, \& Chun, 2012; Urmston, 2003). Factors such as pre-existing beliefs and knowledge (Altan, 2006; Warford \& Reeves, 2003), prior pedagogical experiences (Kourieos, 2014; Polat, 2010), and curriculum-related constraints (Tang et al., 2012) can hinder the development of L2 teaching competence. Other studies, however, have clearly demonstrated that student teachers' beliefs and pedagogical knowledge can develop substantially during SLTE pro- grams (Borg, 2011; Busch, 2010; Farrell, 2009; Wyatt \& Borg, 2011). The implementation of reflective practices, L2 classroom observations, and practical experiences are ways believed to enhance student teacher learning (Cabaroglu \& Roberts, 2000; Farrell, 2015a; Warford \& Reeves, 2003).

Although this line of inquiry has contributed significantly to the understanding of L2 teacher preparation, research on learning to teach pronunciation specifically is only just emerging. Among the few empirical studies available, Golombek and Jordan (2005) showed that a graduate course on pronunciation facilitated positive identity transformation of two Taiwanese learners of pronunciation teaching. Through the course of their study, they began to perceive themselves as credible teachers of English pronunciation. From a teacher cognition perspective - typically examining practitioners' beliefs, knowledge, thoughts, perceptions, and attitudes (Borg, 2006; Burns, Freeman, \& Edwards, 2015) - Buss' (2017) work demonstrated the impact of an undergraduate pronunciation teacher training course on pre-service teachers' cognition, including an increase in "confidence in their ability to teach pronunciation” (p. 217). Prior to Buss’ research, Baker’s (2011a) study revealed a positive relationship between learning to teach pronunciation in a graduate program and instructors' cognition and classroom practices. However, the extent to which graduate student teachers' cognition about English pronunciation develop during a course on pronunciation pedagogy was not examined in these studies.

This research gap led Burri to conduct his doctoral research on student teachers learning to teach English pronunciation in a graduate course on pronunciation pedagogy offered at an Australian tertiary institution. Examining the process of learning to teach pronunciation, identifying factors that facilitated this process, and exploring challenges that student teacher encountered during a course on pronunciation pedagogy was believed to yield new and 
important insights into L2 teacher learning, and, at the same time, make an important contribution to the field of SLTE. The case study aimed at answering the following overarching research question: How and to what extent does student teacher cognition about L2 pronunciation teaching develop during a graduate course on pronunciation pedagogy?

The key findings of the study were disseminated through four journal articles, which provide the basis for conceptualising the framework for pronunciation teacher preparation discussed in the second half of this paper. The aim of the first paper (Burri, 2015a) was to examine the effect the pronunciation course had on participants' cognition about pronunciation. The findings established that a graduate course on pronunciation pedagogy can have an observable impact on the cognition development of student teachers. The paper showed that becoming aware of English varieties and accents fostered teacher learning. An important insight gained from this first paper was that engaging in group work and comparing diverse accents during the semester resulted in participants beginning to see value in non-native varieties of English. In contrast to research proposing that native speakers were more tolerant towards non-native English varieties (Murray, 2003) and research indicating that non-native speakers see "lack of confidence in [non-native speaker] accents as an irresolvable issue" (Jenkins, 2005, p. 541), this study showed that the course fostered a positive change in native speakers and non-native speakers of English towards non-native varieties. Student teachers also developed a better understanding that pronunciation instruction should not aim at eliminating accents.

Building on this preliminary study, the second article (Burri, 2015b) demonstrated that participants' awareness of the importance of teaching suprasegmentals (stress, rhythm, intonation) increased while learning to teach pronunciation. The cognition of participants speaking English as an additional language was enhanced through self-perceived improvement in their own pronunciation and an increase in awareness of their spoken English. The study also revealed that the non-native student teachers gained confidence in their ability to teach pronunciation. This paper provided valuable insights into the preparation of pronunciation teachers, but it did not take into account the participants' previous teaching experiences; an important factor that can influence cognition development (e.g., Kourieos, 2014; Polat, 2010).

The third paper (Burri, Baker, \& Chen, 2017), therefore, explored whether and to what extent student teachers' L2 teaching background had an impact on their cognition development. The research provided evidence that kinaesthetic/ tactile training sessions (e.g., Acton, Baker, Burri, \& Teaman, 2013; Gilbert, 2008) and opportunities for student teachers to observe reallife ESL classrooms con- tributed to the development of participants' cognition about pronunciation pedagogy. However, the intensity/depth of content and the complexity/ambiguity of phonology appeared to restrict cognition growth, particularly in the case of student teachers without any prior pronunciation teaching experience. The findings corroborated Rahimi and Zhang's (2015) work which suggests that practitioners' cognition varies according to the extent of their teaching experience.

Missing from these three studies was an examination of the connection between student teachers' cognition development and their identity construction - the focus of the fourth article (Burri, Chen, \& Baker, 2017). The findings clearly demonstrated that cognition development and identity construction were practically inseparable and that they existed in a mediational relationship that fostered participants' learning to teach English pronunciation. The findings showed that both cognition development and identity construction must be 
considered by teacher educators to prepare L2 instructors successfully. Overall, the four papers provide strong evidence that pronunciation teacher preparation can be effective. Looking at these articles separately, however, provides only a partial view of what learning to teach English pronunciation entails. Hence, the purpose of the present article is to combine the findings of the four papers and propose a new and innovative framework for preparing L2 instructors to teach English pronunciation in their classrooms. Although the model is highly contextualized as we draw from one particular context (an Australian graduate course) and one pool of participants (graduate students in Australia), we trust that the framework will make a valuable contribution to the knowledge-base of English language teacher education.

The next section outlines the methodology used in Burri's doctoral research (from which the four papers were derived) before exploring the model in detail. The final part of the paper will outline the next stage in the project, drawing on interviews and classroom observations.

\section{Methodology}

\section{Study Design}

A qualitative case study approach (Casanave, 2015; Duff, 2008; Stake, 1995) was chosen to examine the preparation of L2 instructors. A case study design allowed for an in-depth understanding of student teachers' learning to teach English pronunciation in a specific context: a 13-week graduate course on pronunciation pedagogy offered at an Australian university.

\section{Participants}

The participants were from Japan ( $n=6)$, Australia ( $(=4)$, Hong Kong $(n=3)$, Iran $(n=1)$, and Pakistan $(\mathrm{n}=1)$. The student teachers from Hong Kong were visiting the university for one semester and were only auditing the course. Of the 15 participants, five had pronunciation teaching experience and 10 spoke English has an additional language. Ten were female and five were male, and their ages ranged from 20 to 60 years with the average age of 31 across the 15 participants. All of the study participants had studied a second or foreign language at some point prior to their graduate studies, even though the length of their studies varied considerably.

Table 1 provides an overview of the participants' background information that was obtained through a questionnaire they were asked to complete at the beginning of the semester (see data collection section below). The participants chose their own pseudonyms. 
Table 1

Background of participants

\begin{tabular}{|c|c|c|c|c|}
\hline $\begin{array}{l}\text { Participant } \\
\text { (pseudonym) }\end{array}$ & $\begin{array}{l}\text { Gender; } \\
\text { Age Range }\end{array}$ & $\begin{array}{l}\text { First } \\
\text { Language }\end{array}$ & $\begin{array}{l}\text { Second } \\
\text { Language } \\
\text { Studied (Years) } \\
\end{array}$ & $\begin{array}{l}\text { Pronunciation Teaching } \\
\text { Experience; Type of Teaching } \\
\text { Experience (Years) }\end{array}$ \\
\hline Koki & M; 20-25 & Japanese & English (10) & No teaching experience \\
\hline Hiro & M; 20-25 & Japanese & English (10) & No teaching experience \\
\hline Mai & F; 31-35 & Japanese & English (10) & No; high school in Japan (6) \\
\hline Aoi & F; 26-30 & Japanese & English (15) & Yes; high school in Japan (5) \\
\hline Mio & $\mathrm{F} ; 41-45$ & Japanese & English (10) & Yes; high school in Japan (6) \\
\hline Ken & M; 36-40 & Japanese & English (10) & Yes; high school in Japan (14) \\
\hline Rio & M; 26-30 & Persian & English (7) & Yes; tertiary level in Iran (8) \\
\hline Hayley & F; 20-25 & Cantonese & $\begin{array}{l}\text { English (since } \\
\text { kindergarten) }\end{array}$ & No teaching experience \\
\hline Mark & M; 20-25 & Cantonese & $\begin{array}{l}\text { English (since } \\
\text { kindergarten) }\end{array}$ & No teaching experience \\
\hline Kirsten & F; 20-25 & Cantonese & $\begin{array}{l}\text { English (since } \\
\text { kindergarten) }\end{array}$ & No teaching experience \\
\hline Grace & F; 20-25 & English & Indonesian (1) & No teaching experience \\
\hline Charlotte & F; 20-25 & English & Spanish (2) & No teaching experience \\
\hline Alizeh & F; 31-35 & $\begin{array}{l}\text { English, } \\
\text { Urdu }\end{array}$ & $\begin{array}{l}\text { Italian (since age } \\
11 \text { ) }\end{array}$ & No teaching experience \\
\hline Lucy & $\mathrm{F} ; 46-50$ & $\begin{array}{l}\text { English, } \\
\text { Dutch }\end{array}$ & $\begin{array}{l}\text { German (since high } \\
\text { school) }\end{array}$ & $\begin{array}{l}\text { No; high school and primary school } \\
\text { in Australia (20) }\end{array}$ \\
\hline Georgia & F; 56-60 & English & French (4) & $\begin{array}{l}\text { Yes; tertiary level in Australia (15- } \\
\text { 20) and primary school in Australia } \\
\text { (2) }\end{array}$ \\
\hline
\end{tabular}

Notes: $\mathrm{M}=$ male; $\mathrm{F}=$ female

\section{Research Context}

The pronunciation pedagogy course was taught by Baker while Burri was the researcher. In the first lecture of the semester, Burri explained to the students that he would have no involvement in the teaching or marking for the course and that their participation (or nonparticipation in the research) would be anonymous, including to the course instructor. The course consisted of weekly topics that were delivered in 3-hour classes held once a week. Table 2 includes an overview of the weekly topics in the pronunciation pedagogy course. These topics were more or less aligned with the course textbook (Celce-Murcia, Brinton, Goodwin, \& Griner, 2010), discussed in further detail below. 
Table 2

Overview of weekly topics covered in pronunciation course

\begin{tabular}{ll}
\hline Week & Topic \\
\hline 1 & Overview of pronunciation instruction \\
2 & Teaching pronunciation through multimodalities \\
3 & Vowels (1) \\
4 & Vowels (2) \\
5 & Syllables, word stress and phrasal stress \\
6 & Tone units, sentence stress and rhythm \\
7 & Intonation \\
8 & Consonants (1) \\
9 & Consonants (2) and connected speech \\
10 & Teaching techniques \\
11 & Fluency development and integrating pronunciation into the curriculum \\
12 & Pronunciation and spelling \\
13 & Presentations \\
\hline
\end{tabular}

Three assessment tasks were included in the pronunciation course. In the first task, the students had to research and discuss the teaching of pronunciation in their home country. The second assessment task was a mid-semester quiz in which the students' knowledge about the English sound system was tested. The last task included a detailed linguistic analysis of an L2 speaker's pronunciation challenges and subsequent pedagogical recommendations for how to improve the speaker's intelligibility.

Teaching pronunciation: A course book and reference guide (Celce-Murcia et al., 2010) was used as the main textbook, while two other books/booklets (Gilbert, 2008; Yates \& Zielinski, 2009) and several journal articles (e.g., Jenkins, 2002; Morgan, 1997; Murphy \& Kandil, 2004) supplemented the core text as either additional or required reading. Several of these supplementary sources were used to facilitate classroom discussion and student teachers' understanding of Australian pronunciation of English. Throughout the course, features of native and non-native English varieties and accents were discussed and analyzed. The instructor advocated a balance between teaching segmentals and suprasegmentals, the integration of pronunciation teaching into other skill areas (e.g., reading, writing, grammar), as well as intelligibility being a more relevant pedagogical goal of pronunciation teaching rather than native-like pronunciation. The course included a strong collaborative element, which required students to engage in peer-teaching sessions and to collaboratively work on theoretical and pedagogical tasks. We acknowledge that the participants were likely influenced by the course content and the style of one particular instructor, and therefore one must exercise caution in generalizing the study's findings to other courses in Australia. 


\section{Data Collection}

Data was gathered from questionnaires, focus group interviews, observations, semi-structured interviews, an assessment task, and the researcher's journal. These various sources permitted triangulation of the data to obtain in-depth understanding of participants' experiences in learning to teach pronunciation. Data collection took place over a period of 16 weeks.

Two questionnaires were administered to collect data on participants' cognition about various areas on pronunciation teaching and learning. The first questionnaire, given at the beginning of the course, was a slight adaption of the one Baker (2011b) developed for her doctoral research. It consisted of 17 multiple- choice items and several open-ended questions. The participants completed the second survey at the end of the course. It contained the same 17 multiple-choice questions and two open-ended questions about participants' homework and their general thoughts on pronunciation teaching and learning. Using the two questionnaires was believed to yield insights into participants' cognition development.

Based on their teaching and linguistic background, participants were divided into four focus groups with each group consisting of three to five students. The participants were put into relatively homogenous groups because it enabled us to attain data specific to certain groups of student teachers (Ho, 2006; Timoštšuk \& Ugaste, 2010). The focus groups met three times during the course of the semester - in weeks 5, 9, and 12 - with each meeting lasting approximately 60 minutes. In each meeting, participants were asked to share a critical incident (Richards \& Farrell, 2005) that occurred in their pronunciation course, enabling us to develop an understanding of the participants' perceptions about learning to teach English pronunciation. In addition to the critical incidents, participants were asked about their learning process, the assessment tasks, and some general questions that arose during the classroom observations.

Burri observed and video-recorded all of the weekly 3-hour lectures. Non- participatory classroom observations, a common tool in teacher cognition research (Borg, 2012), were used to obtain insights into participants' reactions to lecture content. Observation data were also used as stimuli for the focus group meetings and the semi-structured interviews.

Semi-structured interviews, another frequently used source in cognition research (Borg, 2012), elicited information on the participants' beliefs and knowledge about pronunciation upon the completion of the course (i.e., in weeks 13-16). As the focus groups were fairly homogenous, an invitation to participate in a 30-45 minute interview was extended to 1-2 students per group. Mark, Rio, Mio, Hiro, Georgia, Lucy, and Grace agreed to participate. In the interview, several clarification questions (based on focus group and observation data) and scenario-based questions (Borg, 2006) were asked to elicit participants' cognition about pronunciation teaching that the participants may apply in a particular class- room context. In the last week of collecting data (week 17), the lecturer of the course (Baker) was interviewed by the researcher as an additional means of triangulating the collected data and for comparing some of the preliminary findings with her perspective on classroom occurrences.

Participants were also asked to voluntarily share their third assessment task once the lecturer had marked their assignment. The task was collected as part of the data because it provided additional insights into participants' cognition about pronunciation and pronunciation pedagogy. Some of the participants chose not to share their assessment task, and therefore their 5-minute presentation delivered in the last lecture (week 13) was used as a data source. 
Although shorter than the assessment task, the presentation was considered to be equally valid as the talk contained the same content as the participants' final written paper. The student teachers from Hong Kong did not complete the assessment as they were auditing the course; however, the task was discussed with them during the third focus group meeting. Lastly, a research journal was used by Burri to record questions, thoughts, reflections, and emotions about the data (Holliday, 2010), and, at the same time, to maintain "a detailed chronological historical account” (Agostinho, 2005, p. 22) of the research.

\section{Data Analysis}

The focus group, observation, and interview data were transcribed verbatim once the data collection process was concluded. Afterwards, all of the data were coded in NVivo 10 (Bazeley \& Jackson, 2013) based on Baker's (2011b, 2014) previous work. As new themes were discovered, the set of codes was expanded and clustered into thematic categories (Holliday, 2015). According to the focus of each of the four papers described above, these categories were then organized into conceptual displays. Creating displays was an effective way to conceptualize the participants' cognition about pronunciation, as well as to identify factors that affected the student teachers' process of learning to teach English pronunciation.

\section{A Framework for Learning to Teach English Pronunciation}

The research and the resulting four papers provided important insights into the extent to which participants' cognition developed during the pronunciation pedagogy course. As the findings of each paper demonstrated (see summaries above), pronunciation teacher preparation is a multi-faceted undertaking; however, looking at each paper separately only affords a partial view of the complexity of learning to teach English pronunciation. Hence, the aim here is to bring together insights from these papers and put forward a framework to further advance our understanding of preparing pronunciation teachers in an Australian tertiary setting.

As illustrated in the model (see Figure 1), the essence of learning to teach pronunciation lies at the intersection of three significant factors: (1) personal-professional factors, (2) teacher preparation factors, and (3) language factors. These three factors were identified by closely examining the features that impacted the participants' process of learning to teach pronunciation in the four studies discussed above. To varying extents, these factors both contributed to and/or restricted student teachers' learning to teach English pronunciation during the graduate course, and thus need to be fully understood in order to provide the conditions necessary for student teacher learning to occur. The personal-professional category includes aspects related to student teachers' interests, emotions, awareness of spoken language, own pronunciation, imagination of self and others, language background, and teaching experience. Teacher preparation factors, in contrast, encapsulate learning components and opportunities implemented in the pronunciation course: group work/discussion, classroom observations, training sessions, non-native/native collaborations, assessment tasks, professional literature, and course content. Lastly, as the term suggests, language factors include various aspects of language that were covered during the course: accents, English varieties, and phonological ambiguity/complexity.

The three main factors located on the outer periphery of the model are closely interconnected, as represented by the three lines with arrows on each side pointing towards each factor. Yet, 
each factor also substantially contributes to and/or restricts cognition development and identity construction, which is shown by the arrows pointing towards the two circles situated in the centre of the model, and, where these two circles intersect, learning to teach pronunciation actually occurs. The model encompasses what the four journal articles were only able to partially capture on their own. That is, the three factors on the outside of the model should not be viewed as separate components but rather as entities which are woven together by the learner of pronunciation teaching and that serve to mutually sup- port and shape each other; thereby impacting student teachers' cognition development and identity construction (i.e., their pronunciation teaching competence) during the course of their studies, ultimately informing their acquisition of English pronunciation pedagogy.

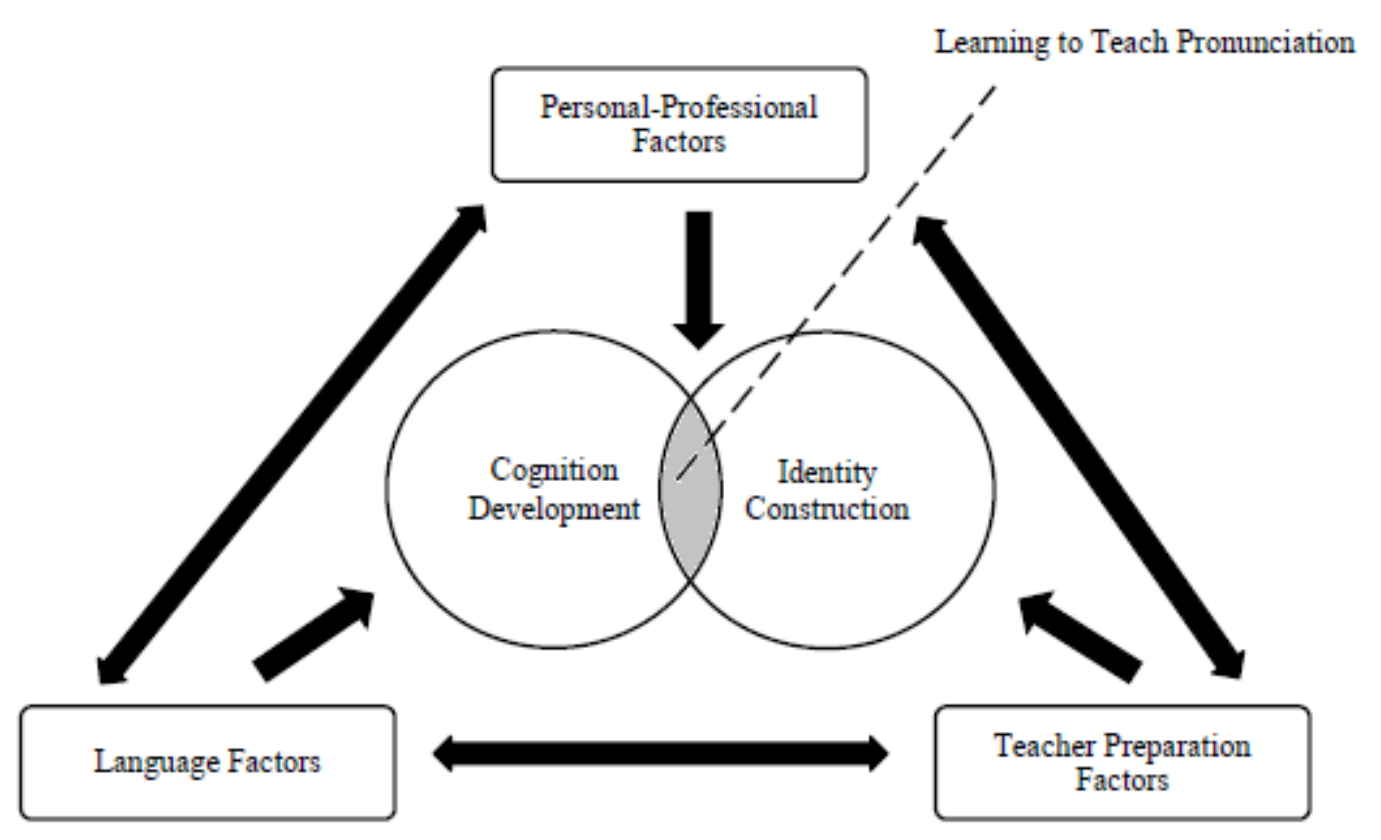

Figure 1. Model of factors that impact pronunciation teacher preparation

Three representative examples demonstrate the interrelationship of the three factors, and their consequent impact on student teacher learning. As a first example, group work/discussions (teacher preparation factor) had a notable reciprocal effect on participants' increased awareness of spoken language and acceptance (i.e., imagination) of non-native speakers being viewed (both by themselves and their native-speaking peers) as capable pronunciation instructors (personal-professional factors) as well as on student teachers' positive perception of English varieties and accents (language factor). Data from a participant (Ken) exemplifies this interrelationship:

I like [group work] now (teacher preparation factor)... because I can compare my pronunciation with others and I can analyze my pronunciation... When I learn pronunciation myself, maybe I cannot find my pronunciation mistakes” (personal-professional factors) (Focus Group 2, Interview 1).

The language factor was subsequently revealed in the post-course questionnaire with his disapproval of the concept of accent elimination. Another illustration of this interrelationship can be seen with the assessment tasks (teacher preparation factor), which facilitated several of the participants' learning but also caused emotional struggles for others (personalprofessional factor) due to the phonological complexity/ambiguity (language factor) and the lack of pronunciation teaching experience of some of the student teachers (personal- 
professional factor). A quote by Alizeh who had no prior teaching experience (personalprofessional factor) highlights this interrelationship:

If I was to do the test (teacher preparation factor) according to the way I speak and the way I hear stuff, it's not wrong, it's just my way of doing it (language factor). So would I be marked [differently]? (personal-professional factor) (Focus Group 3, Interview 2).

One further example was the interconnections between participants' personal interest in subject content (personal-professional factor), their reading of professional literature (teacher preparation factor) and their increased awareness of English varieties and accents (language factor). The connection between these factors is illustrated by Hiro's statement who indicated high levels of engagement with the literature and interest in subject content:

I learned the notion of English as a lingua franca or as an international language (teacher preparation factor / personal-professional factor), so in that context ... non-native speakers don't always have to acquire native-like pronunciation (language factor) (Final Interview).

Embedded within each of these examples is the interconnectedness between participants' cognition development and their identity construction. For each individual teacher, the nature, influence, and actual presence (or absence) of a factor can vary considerably. While various factors may or may not be influential, whichever factors do play a role directly inform or influence both the development of teacher cognition (e.g., gaining of knowledge or changing of belief) and how the teacher simultaneously perceives him/herself (teacher identity) as that development occurs. This important connection thus constitutes the core of pronunciation teacher preparation in our framework. The intersection of the cognition and identity circles forms the heart of the model, representing student teachers' learning to teach English pronunciation.

In essence, this model presents a holistic perspective on learning to teach pronunciation in an Australian graduate course. It highlights the dynamic nature (the interaction of various contributing and restricting factors) of student teachers' learning to teach pronunciation, and it supports the proposition that teacher learning is a complex undertaking, one that is difficult to investigate, characterize, and study (Burns et al., 2015; Kiss, 2012). This multifaceted learning process suggests that developing pronunciation teaching competence is an on-going and constantly evolving endeavor. Yet, it is exactly this interrelated system of various factors that appears to have been one of the course's key elements in facilitating student teachers' acquisition of pronunciation teaching competence. That is, all of the factors affected each other, forming a fruitful learning environment, which facilitated the growth of student teachers' beliefs and knowledge about pronunciation pedagogy. As such, our model, as derived from the four separate studies, suggests that it is this symbiotic relationship of personal-professional, teacher preparation, and language factors, for which L2 educators should aim to enhance their student teachers' learning. Encapsulating this holistic view on preparing pronunciation teachers, the next section discusses implications for L2 teacher educators and processes of L2 teacher education. 


\section{Implications}

Considering the positive effects the course had on the preparation of pronunciation teachers, one implication is that pronunciation needs to be included in graduate TESOL programs. Even though we acknowledge the contextualized nature of the study and its subsequent findings, we think that the model provides compelling evidence that learning to teach pronunciation needs to be part of a TESOL teacher preparation program irrespective of its location. Simply incorporating a course in how to teach pronunciation, however, may not automatically result in sufficient L2 teacher preparation in this area. Thus, we would advise course designers to consult the proposed model (along with other sources) as useful support for developing a context-sensitive pronunciation pedagogy course. As the model demonstrates, preparing pronunciation teachers is not a simple undertaking; it is paramount for course designers and L2 teacher educators to plan their pronunciation courses and the delivery of content around all of the factors identified in the model, with each factor receiving generous consideration in order to enhance the preparation of pronunciation instructors. We would argue that only then can a rich and beneficial learning environment be achieved. Of course, further research is needed to validate this claim. In particular, future research should examine whether some of the factors are potentially more influential in learning to teach pronunciation. Researchers should also explore the role of these factors in pronunciation teacher education delivered in a context other than Australia. One or more of the factors are likely to play an even more important role than others in settings where, for example, English is spoken as an additional language or where government policies mandate the use of particular forms of assessment in a teacher preparation course. This line of inquiry might reveal other factors and concepts that could be used to refine our proposed model, and subsequently further contribute to the understanding of learning to teach pronunciation.

A second implication is the necessity for $\mathrm{L} 2$ teacher educators to draw on rich resources afforded by the diverse backgrounds of students in the SLTE programs they offer. As the study's findings revealed, the diversity of the 15 student teachers, including their language backgrounds, L2 learning experiences, and L2 teaching experiences (or lack thereof), played a crucial role in participants' process of becoming competent pronunciation instructors. Thus, taking student teachers' background into consideration is critical in SLTE. This is a not a new finding, and educators have advocated for contemporary models and practices of SLTE to embrace a sociocultural perspective in order to prepare L2 instructors (e.g., Duff \& Uchida, 1997; Johnson \& Golombek, 2016). What our research demonstrated, however, is that capitalizing on diversity creates a powerful and stimulating learning environment in which student teachers become well equipped to learn to teach pronunciation effectively.

Overall, the model highlights various aspects that contribute to our understanding of what comprises L2 teacher preparation, particularly the development of pronunciation instructors. As such, the model provides an evidence-based theorization of what constitutes effective pronunciation teacher preparation in Australia. The model, however, might also be extended to teacher education pro- grams beyond the realm of learning to teach pronunciation. As the SLTE literature and research demonstrate, learning to teach language is often influenced by factors that align with our model. For instance, pre-existing beliefs and knowledge (personalprofessional factors) (Borg, 2015; Peacock, 2001), program requirements including assessment tasks and curriculum aspects (teacher preparation factors) (Borg, 2009; Macalister, 2016; Tang et al., 2012), student teachers’ own proficiency (language factors) (Golombek \& Jordan, 2005; Park, 2012), and the connection between one's emerging identity and learning to teach (Kanno \& Stuart, 2011) all play important roles in the development of 
L2 teaching competence. Given that the parallel skill areas of grammar and vocabulary are pedagogically comparable to pronunciation instruction (Spada \& Lightbown, 2008), the factors in our model might be particularly relevant to learning to teach grammar and vocabulary. In spite of the wealth of recent teacher cognition research, with the exception of Borg's (2006) model in which he identifies factors that impact practicing L2 teachers' cognition, we are not aware of any theoretical models that conceptualize learning to teach any major aspect of language specific knowledge (vocabulary, pronunciation, grammar). Our model may need to be adapted depending on the skills prospective teacher are prepared to teach and the context in which their learning occurs. It is our hope that this paper leads to further research that assists in the conceptualization of L2 teacher preparation. As such, our proposed model makes an important contribution to the SLTE knowledge- and research-base, at least from the perspective of learning to teach language specific knowledge. With this in mind, factors influencing the learning of other components of language such as vocabulary and grammar may differ or be weighted differently, thus high- lighting that more research is needed in this area.

It should be noted that although the model was drawn from one case study of a graduate course taught at an Australian university, it might not be reflective of what learning to teach pronunciation in other countries entails. However, as the diversity of the student teacher population in many TESOL programs around the world has become a reality (Carrier, 2003), the model will have wider applications to TESOL programs elsewhere. Further research should be conducted in this area to examine whether learning to teach English pronunciation is perhaps more con- text-specific than sometimes recognized.

\section{Future Research Direction and Conclusion}

The next step with this line of inquiry is to collect fresh data and elicit the participating teachers' current pronunciation beliefs and practices in order to compare them with their cognition acquired during the a pronunciation pedagogy course. We expect this research to yield further insights into how well such courses prepare their participants for teaching pronunciation in their L2 classrooms, especially since the cognition and actual practices of a teacher often do not correspond (Basturkmen, 2012; Borg, 2006). We believe that the continuation of this research is particularly important given that the "the development of pedagogical content knowledge emerges out of engagement in the activities of teaching since its very nature constitutes the interconnectedness of content, context, students, and pedagogical purpose" (Johnson, 2015, p. 519). Thus, seeking to understand the relation- ship between teachers' cognition and actual pronunciation teaching practices will extend our understanding of the effectiveness of preparing pronunciation teachers. This will eventually help us refine the conceptual model discussed in this paper, which, in turn, should make it more generalizable to other areas of language teaching and thus more useful for L2 teacher educators and researchers.

In conclusion, the newly developed model offers insights into the preparation of pronunciation instructors which encompasses an interwoven and multifaceted relationship between cognition development, identity construction, personal-professional factors, teacher preparation factors, and language factors. Simultaneously, the model presents a compelling argument that pronunciation should be given a more prominent place in TESOL programs than has been the case to date (Foote et al., 2011; Henderson et al., 2012; Murphy, 2014). Yet, although teacher learning does not end upon the completion of a L2 teacher education 
program (Johnson, 2015), this model indicates that the student teachers who participated in our research are well on their way to becoming competent and effective pronunciation instructors. Future research will consequently examine that competency and effectiveness as represented in the teachers' current classrooms.

\section{Acknowledgements}

This research project was funded by the University of Wollongong Postgraduate Award. We would like to express our gratitude to the 15 student teachers who took part in this study. With- out their participation, the design of this framework would not have been possible. We would also like to thank the two anonymous reviewers for their helpful comments.

\section{References}

Acton, W., Baker, A. A., Burri, M., \& Teaman, B. (2013). Preliminaries to haptic-integrated pronunciation instruction. In J. Levis \& K. LeVelle (Eds.), Proceedings of the 4th Pronunciation in Second Language Learning and Teaching Conference (pp. 234-244). Ames, IA: Iowa State University.

Agostinho, S. (2005). Naturalistic inquiry in e-learning research. International Journal of Qualitative Methods, 4(1), 13-26. https://doi.org/10.1177/160940690500400102

Altan, M. Z. (2006). Beliefs about language learning of foreign language major university students. Australian Journal of Teacher Education, 31(2), 45-52. https://doi.org/10.14221/ajte.2006v31n2.5

Baker, A. A. (2011a). ESL teachers and pronunciation pedagogy: Exploring the development of teachers' cognitions and classroom practices. In J. Levis \& K. LeVelle (Eds.), Proceedings of the 2nd Pronunciation in Second Language Learning and Teaching Conference (pp. 82-94). Aimes, IA: Iowa State University.

Baker, A. A. (2011b). Pronunciation pedagogy: Second language teacher cognition and practice (Unpublished doctoral dissertation). Georgia State University, GA.

Baker, A. A. (2014). Exploring teachers' knowledge of L2 pronunciation techniques: Teacher cognitions, observed classroom practices and student perceptions. TESOL Quarterly, 48(1), 136-163. https://doi.org/10.1002/tesq.99

Basturkmen, H. (2012). Review of research into the correspondence between language teachers' stated beliefs and practices. System, 40(2), 282-295. https://doi.org/10.1016/j.system.2012.05.001

Bazeley, P., \& Jackson, K. (2013). Qualitative data analysis with NVivo (2nd ed.). Thousand Oaks, CA: Sage Publications Inc.

Borg, S. (2006). Teacher cognition and language education: Research and practice. London: Continuum.

Borg, S. (2009). Language teacher cognition. In A. Burns \& J. C. Richards (Eds.), The Cambridge guide to second language teacher education (pp. 163-171). New York, NY: Cambridge University Press.

Borg, S. (2011). The impact of in-service teacher education on language teachers' beliefs. System, 39(3), 370-380. https://doi.org/10.1016/j.system.2011.07.009

Borg, S. (2012). Current approaches to language teacher cognition research: A methodological analysis. In R. Barnard \& A. Burns (Eds.), Researching language teacher cognition and practice: International case studies (pp. 11-29). Bristol:

Multilingual Matters. https://doi.org/10.21832/9781847697912-003 
Borg, S. (2015). Researching language teacher education. In B. Paltridge \& A. Phakiti (Eds.), Research methods in applied linguistics: A practical resource (pp. 541-560). New York, NY: Bloomsbury.

Burns, A., Freeman, D., \& Edwards, E. (2015). Theorizing and studying the languageteaching mind: Mapping research on language teacher cognition. The Modern Language Journal, 99(3), 585-601. https://doi.org/10.1111/mol.12245

Burns, A., \& Richards, J. C. (2009). Second language teacher education. In A. Burns \& J. C. Richards (Eds.), The Cambridge guide to second language teacher education (pp. 1-8). Cambridge: Cambridge University Press.

Burri, M. (2015a). "My perspective changed dramatically”: A case for preparing L2 instructors to teach pronunciation. English Australia Journal, 31(1), 19-37.

Burri, M. (2015b). Student teachers' cognition about L2 pronunciation instruction: A case study. Australian Journal of Teacher Education, 40(10), 66-87. https://doi.org/10.14221/ajte.2015v40n10.5

Burri, M., Baker, A. A., \& Chen, H. (2017). "I feel like having a nervous breakdown”: Preservice and in-service teachers' developing beliefs and knowledge about pronunciation instruction. Journal of Second Language Pronunciation, 3(1), 109-135. https://doi.org/10.1075/jslp.3.1.05bur

Burri, M., Chen, H., \& Baker, A. A. (2017). Joint development of teacher cognition and identity through learning to teach L2 pronunciation. The Modern Language Journal, 101(1), 128-142. https://doi.org/10.1111/modl.12388

Busch, D. (2010). Pre-service teacher beliefs about language learning: The second language acquisition course as an agent for change. Language Teaching Research, 14(3), 318337. https://doi.org/10.1177/1362168810365239

Buss, L. (2017). The role of training in shaping pre-service teacher cognition related to L2 pronunciation. Ilha do Desterro, 70, 201-226. https://doi.org/10.5007/21758026.2017v70n3p201

Cabaroglu, N., \& Roberts, J. (2000). Development in student teachers’ pre-existing beliefs during a 1-year PGCE programme. System, 28(3), 387-402. https://doi.org/10.1016/S0346-251X(00)00019-1

Carrier, K. A. (2003). NNS teacher trainees in Western-based TESOL programs. ELT Journal, 57(3), 242-250. https://doi.org/10.1093/elt/57.3.242

Casanave, C. P. (2015). Case studies. In B. Paltridge \& A. Phakiti (Eds.), Research methods in applied linguistics: A practical resource (pp. 118-135). New York, NY: Bloomsbury.

Celce-Murcia, M., Brinton, D., Goodwin, J., \& Griner, B. (2010). Teaching pronunciation: A course book and reference guide (2nd ed.). New York, NY: Cambridge University Press.

Couper, G. (2017). Teacher cognition of pronunciation teaching: Teachers' concerns and issues. TESOL Quarterly, 51(4), 820-843. https://doi.org/10.1002/tesq.354

Derwing, T. M., \& Munro, M. J. (2015). Pronunciation fundamentals: Evidence-based perspectives for L2 teaching and research. Philadelphia, PA: John Benjamin Publishing Company.

Duff, P. A. (2008). Case study research in applied linguistics. New York, NY: Lawrence Erlbaum Associates.

Duff, P. A., \& Uchida, Y. (1997). The negotiation of teachers' sociocultural identities and practices in postsecondary EFL classrooms. TESOL Quarterly, 31(3), 451-486. https://doi.org/10.2307/3587834 
Farrell, T. S. C. (2009). Critical reflection in a TESL course: Mapping conceptual change. ELT Journal, 63(3), 221-229. https://doi.org/10.1093/elt/ccn058

Farrell, T. S. C. (2015a). Promoting teacher reflection in second language education: A framework for TESOL professionals. New York, NY: Routledge.

Farrell, T. S. C. (2015b). Second language teacher education: A reality check. In T. S. C. Farrell (Ed.), International perspectives on English language teacher education: Innovations from the field (pp. 1-15). New York, NY: Palgrave Macmillan.

Foote, J. A., Holtby, A. K., \& Derwing, T. M. (2011). Survey of the teaching pronunciation in adult ESL programs in Canada, 2010. TESL Canada Journal, 29(1), 1-22. https://doi.org/10.18806/tesl.v29i1.1086

Freeman, D., \& Johnson, K. E. (1998). Reconceptualizing the knowledge-base of language teacher education. TESOL Quarterly, 32(3), 397-417. https://doi.org/10.2307/3588114

Gilbert, J. (2008). Teaching pronunciation: Using the prosody pyramid. New York, NY: Cambridge University Press.

Golombek, P. R., \& Jordan, S. R. (2005). Becoming “black lambs” not “parrots”: A poststructuralist orientation to intelligibility and identity. TESOL Quarterly, 39(3), 513-533. https://doi.org/10.2307/3588492

Henderson, A., Frost, D., Tergujeff, E., Kautzsch, A., Murphy, D., Kirkova-Naskova, A., ... Curnick, L. (2012). The English pronunciation teaching in Europe survey: Selected results. Research in Language, 10(1), 5-27. https://doi.org/10.2478/v10015-011-00474

Ho, D. (2006). The focus group interview: Rising to the challenge in qualitative research methodology. Australian Review of Applied Linguistics, 29(1), 05.01-05.19. https://doi.org/10.2104/aral0605

Holliday, A. (2010). Analysing qualitative data. In B. Paltridge \& A. Phakiti (Eds.), Continuum companion to research methods in applied linguistics (pp. 98-110). New York, NY: Continuum.

Holliday, A. (2015). Qualitative research and analysis. In B. Paltridge \& A. Phakiti (Eds.), Research methods in applied linguistics: A practical course (pp. 49-62). New York, NY: Bloomsbury.

Jenkins, J. (2005). Implementing an international approach to English pronunciation: The role of teacher attitudes and identity. TESOL Quarterly, 39(3), 535-543. https://doi.org/10.2307/3588493

Jenkins, J. (2002). A sociolinguistically based, empirically researched pronunciation syllabus for English as an international language. Applied Linguistics, 23(1), 83-103. https://doi.org/10.1093/applin/23.1.83

Johnson, K. E. (2006). The sociocultural turn and its challenges for second language teacher education. TESOL Quarterly, 40(1), 235-257. https://doi.org/10.2307/40264518

Johnson, K. E. (2015). Reclaiming the relevance of L2 teacher education. The Modern Language Journal, 99(3), 515-528. https://doi.org/10.1111/modl.12242

Johnson, K. E., \& Golombek, P. R. (2016). Mindful L2 teacher education: A sociocultural perspective on cultivating teachers' professional development. New York, NY: Routledge.

Kang, O., Thomson, R. I., \& Murphy, J. (Eds.). (2018). The Routledge handbook of contemporary English pronunciation. New York, NY: Routledge.

Kanno, Y., \& Stuart, C. (2011). Learning to become a second language teacher: Identities-inpractice. The Modern Language Journal, 95(2), 236-252.

https://doi.org/10.1111/j.1540-4781.2011.01178.x 
Kelly, L. G. (1969). 25 centuries of language teaching: 500BC - 1969. Rowley, MA: Newbury House Publishers.

Kiss, T. (2012). The complexity of teacher learning: Reflection as a complex dynamic system. Journal of Interdisciplinary Research in Education, 2(1), 17-35.

Kourieos, S. (2014). The knowledge base of primary EFL teachers: Pre-service and in-service teachers’ perceptions. Journal of Language Teaching and Research, 5(2), 291-300. https://doi.org/10.4304/jltr.5.2.291-300

Lee, J., Jang, J., \& Plonsky, L. (2015). The effectiveness of second language pronunciation instruction: A meta-analysis. Applied Linguistics, 36(3), 345-366. https://doi.org/10.1093/applin/amu040

Levis, J. (2015). Pronunciation trends across journals and the journal of second language pronunciation. Journal of Second Language Pronunciation, 1(2), 129-134. https://doi.org/10.1075/jslp.1.2.001edi

Litzenberg, J. (2014). Pre-service teacher perspectives towards pedagogical uses of nonnative and native speech samples. International Journal of Applied Linguistics, 26(2), 168-189. https://doi.org/10.1111/ijal.12084

Macalister, J. (2016). Tracing it back: Identifying the impact of a trans-national language teacher education programme on classroom practice. RELC Journal, 47(1), 59-70. https://doi.org/10.1177/0033688216631204

Morgan, B. (1997). Identity and intonation: Linking dynamic processes in an ESL classroom. TESOL Quarterly, 31(3), 431-450. https://doi.org/10.2307/3587833

Murphy, J. (2014). Teacher training programs provide adequate preparation in how to teach pronunciation. In L. Grant (Ed.), Pronunciation myths: Applying second language research to classroom teaching (pp. 188-224). Ann Arbor, MI: The University of Michigan Press.

Murphy, J., \& Kandil, M. (2004). Word-level stress patterns in the academic word list. System, 32, 61-74. https://doi.org/10.1016/j.system.2003.06.001

Murray, H. (2003). Swiss English teachers and Euro-English: Attitudes to a non-native variety. Bulletin VALS-ASLA, 77, 147-165.

Ogilvie, G., \& Dunn, W. (2010). Taking teacher education to task: Exploring the role of teacher education in promoting the utilization of task-based language teaching. Language Teaching Research, 14(2), 161-181. https://doi.org/10.1177/1362168809353875

Park, G. (2012). “I am never afraid of being recognized as an NNES”: One teacher's journey in claiming and embracing her nonnative-speaker identity. TESOL Quarterly, 46(1), 127-151. https://doi.org/10.1002/tesq.4

Peacock, M. (2001). Pre-service ESL teachers’ beliefs about second language learning: A longitudinal study. System, 29(2), 177-195. https://doi.org/10.1016/S0346251X(01)00010-0

Polat, N. (2010). A comparative analysis of pre-and in-service teacher beliefs about readiness and self-competency: Revisiting teacher education for ELLs. System, 38(2), 228-244. https://doi.org/10.1016/j.system.2010.03.004

Rahimi, M., \& Zhang, L. (2015). Exploring non-native English-speaking teachers’ cognitions about corrective feedback in teaching English oral communication. System, 55, 111122. https://doi.org/10.1016/j.system.2015.09.006

Reed, M., \& Levis, J. (Eds.). (2015). The handbook of English pronunciation. Malden, MA: Wiley Blackwell. 
Richards, J. C. (1990). The dilemma of teacher education in second language teaching. In J. C. Richards \& D. Nunan (Eds.), Second language teacher education (pp. 3-15). Cambridge: Cambridge University Press.

Richards, J. C., \& Farrell, T. S. C. (2005). Professional development for language teachers. Cambridge: Cambridge University Press.

Saito, K. (2012). Effects of instruction on L2 pronunciation development: A synthesis of 15 quasi-experimental intervention studies. TESOL Quarterly, 46(4), 842-854. https://doi.org/10.1002/tesq.67

Spada, N., \& Lightbown, P. M. (2008). Form-focused instruction: Isolated or integrated. TESOL Quarterly, 42(2), 181-207. https://doi.org/10.1002/j.1545-7249.2008.tb00115.x

Stake, R. E. (1995). The art of case study research. Thousand Oaks, CA: Sage Publications, Inc.

Tang, E. L., Lee, J. C., \& Chun, C. K. (2012). Development of teaching beliefs and the focus of change in the process of pre-service ESL teacher education. Australian Journal of Teacher Education, 37(5), 90-107. https://doi.org/10.14221/ajte.2012v37n5.8

Thomson, R. I. (2014). Accent reduction and pronunciation instruction are the same thing. In L. Grant (Ed.), Pronunciation myths: Applying second language research to classroom teaching (pp. 160-187). Ann Arbor, MI: The University of Michigan Press.

Thomson, R. I., \& Derwing, T. M. (2015). The effectiveness of L2 pronunciation instruction: A narrative review. Applied Linguistics, 36(3), 326-344. https://doi.org/10.1093/applin/amu076

Timoštšuk, I., \& Ugaste, A. (2010). Student teachers' professional identity. Teaching and Teacher Education, 26(8), 1563-1570. https://doi.org/10.1016/j.tate.2010.06.008

Urmston, A. (2003). Learning to teach English in Hong Kong: The opinions of teachers in training. Language and Education, 17(2), 112-137. https://doi.org/10.1080/09500780308666843

Warford, M. K., \& Reeves, J. (2003). Falling into it: Novice TESOL teacher thinking. Teachers and Teaching: Theory and Practice, 9(1), 47-65. https://doi.org/10.1080/1354060032000049904

Wright, T. (2010). Second language teacher education: Review of recent research on practice. Language Teaching, 43(3), 259-296. https://doi.org/10.1017/S0261444810000030

Wright, T., \& Beaumont, M. (2015). Introduction. In T. Wright \& M. Beaumont (Eds.), Experiences of second language teacher education (pp. 1-14). New York, NY: Palgrave Macmillan.

Wyatt, M., \& Borg, S. (2011). Development in the practical knowledge of language teachers: A comparative study of three teachers designing and using communicative tasks on an in-service BA TESOL programme in the Middle East. Innovation in Language Learning and Teaching, 5(3), 233-252. https://doi.org/10.1080/17501229.2010.537340

Yates, L., \& Zielinski, B. (2009). Give it a go: Teaching pronunciation to adults. Sydney, NSW: AMEP Research Centre. 